Article

\title{
Mechanistic Insight into the Ring-Opening Polymerization of $\varepsilon$-Caprolactone and $L$-Lactide Using Ketiminate-Ligated Aluminum Catalysts
}

\author{
Ya-Fan Lin ${ }^{1,2, *(1)}$ and Nai-Yuan Jheng ${ }^{2}$ \\ 1 Department of Fragrance and Cosmetic Science, Kaohsiung Medical University, Kaohsiung 80708, Taiwan \\ 2 Department of Medicinal and Applied Chemistry, Kaohsiung Medical University, Kaohsiung 80708, Taiwan; \\ pkjaster@gmail.com \\ * Correspondence: yafan@kmu.edu.tw; Tel.: +886-7-3121101 (ext. 2818)
}

Received: 14 August 2019; Accepted: 17 September 2019; Published: 19 September 2019

check for updates

\begin{abstract}
The reactivity and the reaction conditions of the ring-opening polymerization of $\varepsilon$-caprolactone ( $\varepsilon$-CL) and $L$-lactide (LA) initiated by aluminum ketiminate complexes have been shown differently. Herein, we account for the observation by studying the mechanisms on the basis of density functional theory (DFT) calculations. The calculations show that the ring-opening polymerization of $\varepsilon$-CL and LA are rate-determined by the benzoxide insertion and the $\mathrm{C}-\mathrm{O}$ bond cleavage step, respectively. Theoretical computations suggest that the reaction temperature of $L-L A$ polymerization should be higher than that of $\varepsilon$-CL one, in agreement with the experimental data. To provide a reasonable interpretation of the experimental results and to give an insight into the catalyst design, the influence of the electronic, steric, and thermal effects on the polymerization behaviors will be also discussed in this study.
\end{abstract}

Keywords: DFT calculation; ring-opening polymerization; L-lactides; $\varepsilon$-caprolactone; aluminum complexes; ketiminate ligands

\section{Introduction}

Utilization of the polyester such as poly( $\varepsilon$-caprolactone) (PCL) and poly(L-lactide) (PLA) as eco-friendly materials has been paid more and more attention [1-6]. Therefore, development of efficient synthetic strategies becomes of great interest to chemists. Among these strategies, ring-opening polymerization (ROP) catalyzed by the less toxic and inexpensive aluminum complexes is one of the useful and well-controlled methods [7-30]. The ring-opening polymerization catalyzed by an organometallic complex usually proceeds through a coordination-insertion mechanism [31,32]. Recent works have revealed that coordination number [33-35], the size effect of the chelate rings [36], steric and electronic effects of the auxiliary ligands surrounding the aluminum complexes $[22,25,34,37-44]$ as well as the co-initiators would alter the reactivity and the properties of the products. Besides the reaction conditions would be very dependent on the ring size and the bulkiness of the monomers $[45,46]$. For example, $L$-lactide has been found to be bulkier than caprolactone since the Al-O bond enthalpy of the former are weaker than the later [47]. Several kinds of Al complexes as the initiators for the ring opening polymerization have been designed, and different factors that influence the reactivity have been discussed separately. Nevertheless, systematically studying the structures-activity relationship of the catalysts remains ongoing.

In 2015, Chen et al. reported a series of aluminum complexes bearing ketiminate ligands to process the ring-opening polymerization of both $\varepsilon$-caprolactone ( $\varepsilon$-CL) and L-lactide (L-LA) (Figure 1) [48,49]. By screening the pendant groups on the ketiminate skeleton of the aluminum complexes, the steric, 
electronic and chelating effects of the ring-opening polymerization of $\varepsilon$-caprolactone and $L$-lactide could be delineated by comparison of the experimental results. Previous experimental data has revealed that in the ketiminate-ligated $\mathrm{Al}$ systems, ring-opening polymerization of $\varepsilon$-caprolactone can proceed at room temperature. Nevertheless, if using L-lactide as a monomer, similar reactions cannot occur until raising up temperature to $333 \mathrm{~K}$. Besides, the $k_{\text {obs }}$ values of the ring-opening polymerization are influenced by the steric and electronic effects on the pendant $\mathrm{N}$ donors of kind of $\mathrm{Al}$ complex. It is worth noting that the orders of $k_{\text {obs }}$ values in the polymerization of $\varepsilon$-caprolactone and L-LA have different tendencies. For examples, catalysts with the bulky isopropyl substituents facilitates the polymerization of $\varepsilon$-caprolactone, but formation of polylactide is not promoted by this kind $\mathrm{Al}$ complex (Figure 2). To get more insight into the mechanism, we decided to employ density functional theory (DFT) calculation to compare the two ring-opening polymerization systems catalyzed by the $\mathrm{Al}$ complex bearing a ketiminate ligand. Although only few cases of tetradentate $\mathrm{Al}$ catalysts have been evaluated by DFT calculations [50-52], it has been proven to be a useful tool to model the reaction intermediates and comprehend the reaction pathways of the tris- and penta-coordinate $\mathrm{Al}$ complexes [29,42,44,52-62]. Our aims in this theoretical study are: (a) to realize why polymerization of $\varepsilon$-caprolactone and $L$-lactide require different reaction temperatures; (b) to understand how the steric and electronic effects on the pendant group of the Al complexes would alter the catalytic abilities. To answer the above questions, we tried to compute the entire reaction pathways and estimate the activation barriers of the rate-determining steps. For the thermodynamic consideration, we also evaluated the bond enthalpy for the monomer coordination to the $\mathrm{Al}$ center. In addition, we chose L, $\mathrm{L}^{\mathrm{Cl}}$, and $\mathrm{L}^{i \mathrm{Pr}}$ (Figure 1 ) as pendant groups of the catalysts to evaluate the electronic and steric effects in both poly( $\varepsilon$-caprolactone $)$ and poly(L-lactide) synthesis.

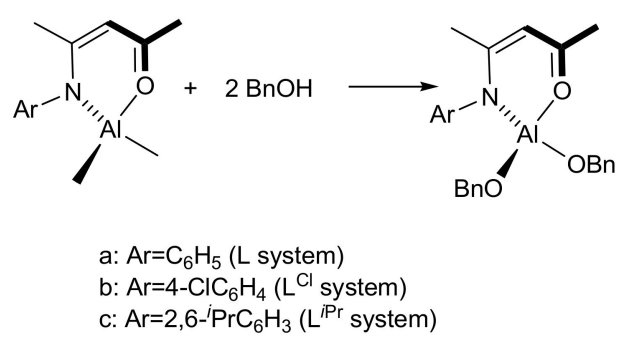

Figure 1. A series of aluminum ketiminate complexes bearing different substituents for the ring-opening polymerization of $\varepsilon$-caprolactone and $L$-lactide.

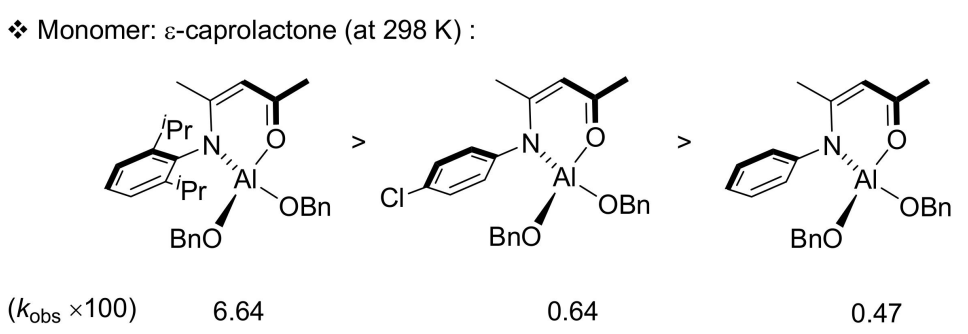

* Monomer: L-lactide (at $333 \mathrm{~K}$ ) :

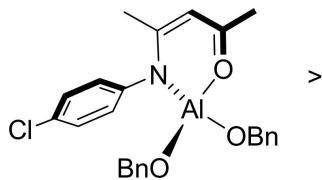

$\left(k_{\mathrm{obs}} \times 100\right)$

2.44

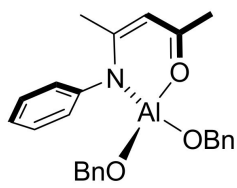

1.68

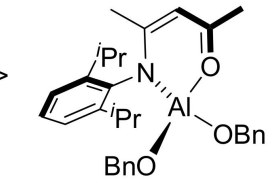

0.76

Figure 2. Experimental data summary for the ring-opening polymerization of $\varepsilon$-caprolactone and L-lactide initiated by aluminum ketiminate complexes. 


\section{Materials and Methods}

All the energies and the geometries for the intermediates and transition states were evaluated using the Gaussian 16 package (Gaussian Inc., Pittsburgh, PA, USA) [63]. The Becke 3-parameter Lee-Yang Parr (B3LYP) hybrid functional combined with the D3 empirical dispersion correction developed by Grimme and the 6-31g(d) basis set was chosen as the calculation level [64-71]. The polarizable continuum model (PCM) was employed to describe the solvent effect of toluene [72]. To identify all the stationary-point structures, all reaction species were subjected to perform the frequency computation. All the resting states show real values in all types of motional frequencies, while the species with only one imaginary frequency were confirmed as transition states. Finally, the intrinsic reaction coordinate (IRC) or Quasi-IRC calculations were employed to make sure the connection between intermediates and the transition state [73-76]. The optimized Cartesian coordinates for all structures are provided in the Supplementary Materials.

\section{Results and Discussion}

Ring-opening polymerization of $\varepsilon$-caprolactone and L-lactide catalyzed by $\mathrm{Al}$ complexes would follow the coordination-insertion mechanism. The process starts from monomer coordination to the $\mathrm{Al}$ center, followed by benzoxide insertion to the $\mathrm{C}=\mathrm{O}$ group of the monomer. Then, the resultant intermediate adjusts to the proper conformation to facilitate the breakage of $\mathrm{C}-\mathrm{O}$ bond, completing the first ring-opening process. In the ketiminate-ligated $\mathrm{Al}$ systems, the monomer is approaching the $\mathrm{Al}$ center to give a penta-coordinate species. Considering 13 possible isomers can be generated, all of them were submitted as initial geometries and optimized by DFT calculation. (Figure 3). Calculation results show that only isomer I, II, III, and IV can be obtained as the optimal geometries, so mechanisms starting from isomer V-XIII are not considered. In order to obtain a more comprehensive view of the ROP mechanism, we discussed the four possible pathways from four triangular bipyramidal (TBP) isomer I-IV as the starting species (Scheme 1). By scanning the reaction coordinates, we confirmed that for the species $\mathrm{N}$ donor resides in the axial site (isomer III and IV), the monomer tends to be driven away from the aluminum center when benzoxide is approaching. As a result, Route 3 and 4 in Scheme 1 can be ruled out. The mechanistic calculations were concentrated on the pathways starting from I and II, which are initiated from the coordination isomers with the axial O donor (Route 1 and 2: the starting species is the isomer that monomer respectively coordinates on the equatorial and axial site).

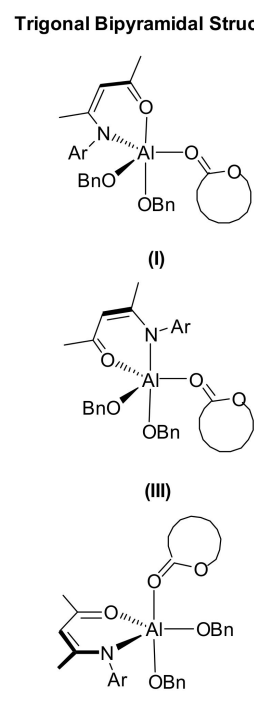

(V)

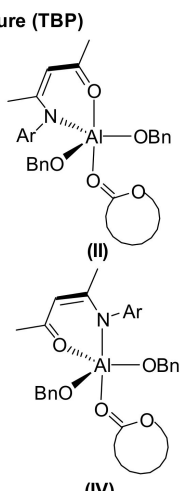

(IV)

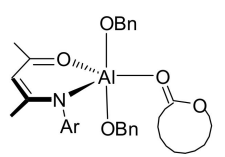

(VI)

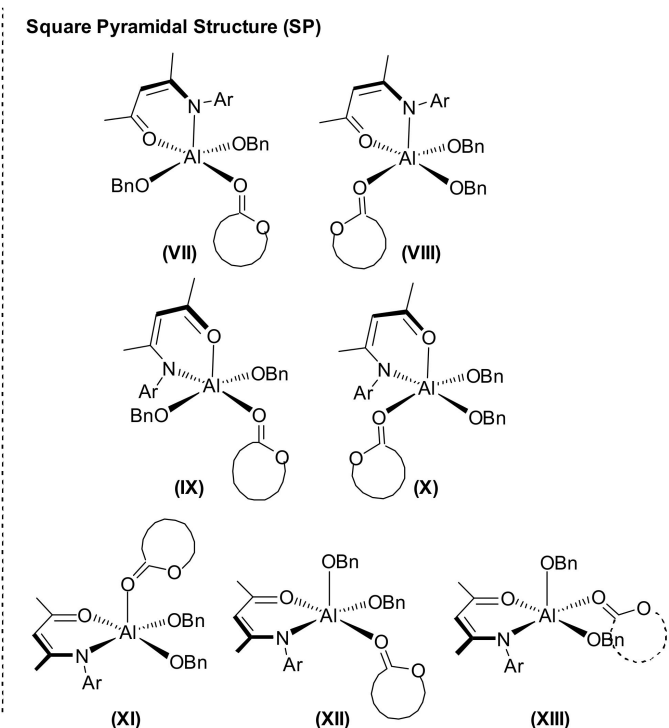

(XI)

(XII)
(XIII)<smiles>CCCCCCCOC1CCCCC1=O</smiles>

Figure 3. Thirteen possible initial geometries considered in this study. 


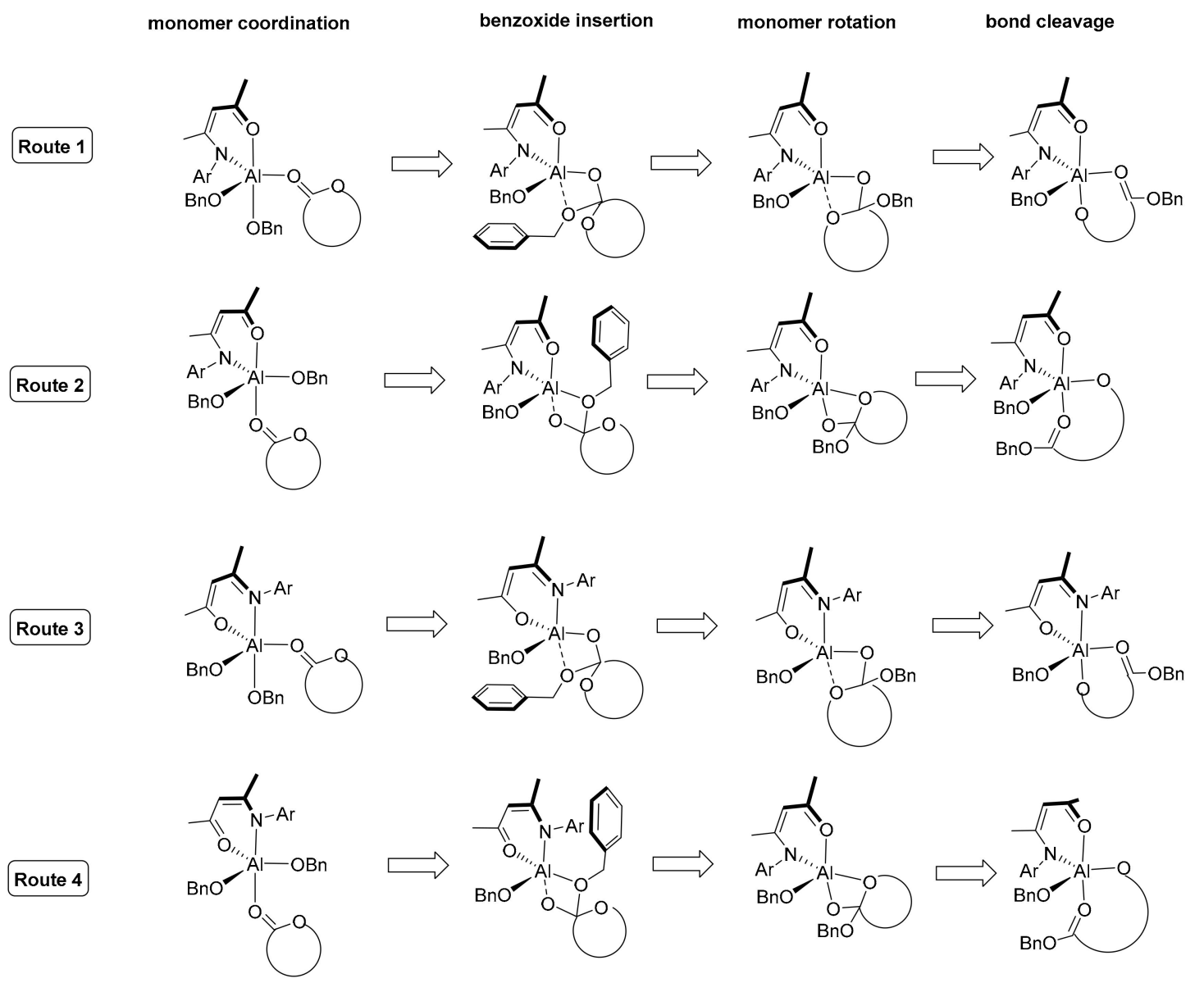

Scheme 1. Four possible routes starting from four different triangular bipyramidal (TBP) monomer-coordinated aluminum isomers and follow the coordination-insertion mechanism.

\subsection{Ring-Opening Polymerization of $\varepsilon$-Caprolactone}

Computing results showed that $\varepsilon$-caprolactone can occupy either equatorial or axial sites to give coordinated species in all three systems with different pendant groups. The $\varepsilon$-caprolactone equatorially and axially coordinated isomers are respectively denoted as $\mathrm{C}_{\mathrm{eq}} 1 \mathrm{a}-\mathrm{c}$ and $\mathrm{C}_{\mathrm{ax}} 1 \mathrm{a}-\mathrm{c}\left(\mathrm{a}: \mathrm{L}, \mathrm{b}: \mathrm{L}^{\mathrm{Cl}}, \mathrm{c}\right.$ : $\mathrm{L}^{\mathrm{ipr}}$; Figure 4). The $\mathrm{Al}-\mathrm{O} 2\left(\mathrm{Al}-\mathrm{O}_{\mathrm{CL}}\right)$ bond lengths in $\mathrm{C}_{\mathrm{eq}} 1 \mathrm{a}, \mathrm{C}_{\mathrm{eq}} 1 \mathrm{~b}$, and $\mathrm{C}_{\mathrm{eq}} 1 \mathrm{c}$ are respectively 2.013, 2.012, and $2.024 \AA$, shorter than those in $\mathrm{C}_{\mathrm{ax}} 1 \mathrm{a}-\mathrm{c}\left(\mathrm{C}_{\mathrm{ax}} 1 \mathrm{a}\right.$ and $\left.\mathrm{C}_{\mathrm{ax}} 1 \mathrm{~b}: 2.069 ; \mathrm{C}_{\mathrm{ax}} 1 \mathrm{c}: 2.085 \AA\right)$. However, the bond enthalpies of Al-caprolactone in $C_{a x} 1 a-c\left(C_{a x} 1 a:-12.7 ; C_{a x} 1 b:-13.4 ; C_{a x} 1 \mathrm{c}:-9.1 \mathrm{kcal} / \mathrm{mol}\right)$ are slightly larger than those in $\mathrm{C}_{\mathrm{eq}} 1 \mathrm{a}-\mathrm{c}\left(\mathrm{C}_{\mathrm{eq}} 1 \mathrm{a}:-9.4 ; \mathrm{C}_{\mathrm{eq}} 1 \mathrm{~b}:-10.4 ; \mathrm{C}_{\mathrm{eq}} 1 \mathrm{c}:-7.5 \mathrm{kcal} / \mathrm{mol}\right)$, showing coordination of $\varepsilon$-caprolactone at the axial site is energetically favorable. Both the equatorial and axial caprolactone coordination orientation are affected by the steric effect. Bulky substituents of isopropyl groups would hinder the monomer coordination. As a result, the bond enthalpies in the $L^{i P r}$ systems are the smallest among the three systems. On the other hand, the fact the $\mathrm{Al}-\mathrm{O} 2$ bond enthalpies in the $\mathrm{L}^{\mathrm{Cl}}$ systems are largest can be attributed to the chloro substituent, whose electron withdrawing property would make the $\mathrm{Al}$ center more positive and favorably binding to the $\varepsilon$-caprolactone. 

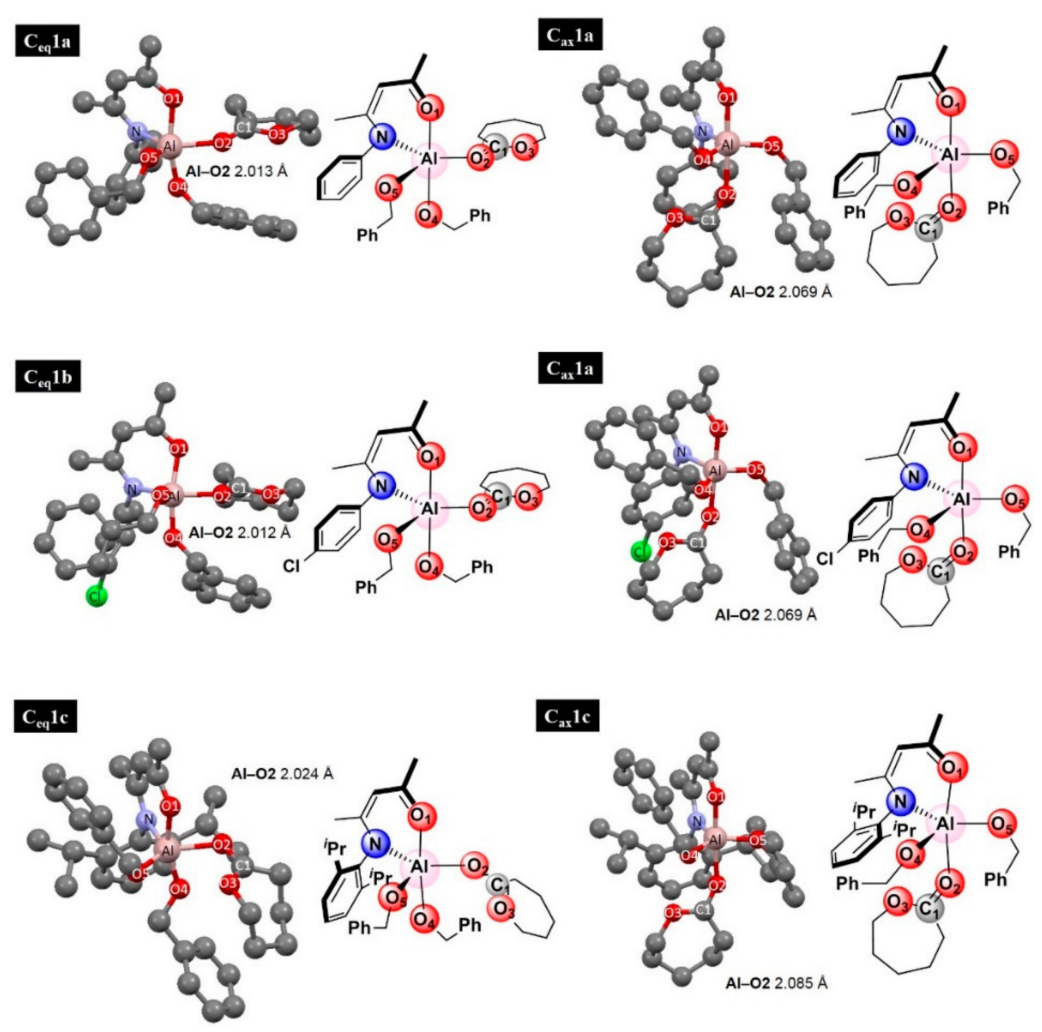

Figure 4. $\varepsilon$-Caprolactone coordinated aluminum complexes which bear $\mathrm{L}, \mathrm{L}^{\mathrm{Cl}}$, and $\mathrm{L}^{\mathrm{iPr}}$ ligand systems and arrange in a TBP fashion.

The Gibbs free energy profiles are shown in Figures 5-7. The calculations reveal that the benzoxide insertion is the rate determining step of the $\varepsilon$-caprolactone ring-opening polymerization. The relative Gibbs energies in Route 1 are computed as $14.4 \mathrm{kcal} / \mathrm{mol}$ for $\mathrm{C}_{\mathrm{eq}} \mathrm{TS} 1 \mathrm{a}, 14.9$ for $\mathrm{C}_{\mathrm{eq}} \mathrm{TS} 1 \mathrm{~b}$, and 13.2 for $\mathrm{C}_{\mathrm{eq}}$ TS1c (The differences in barrier height between $\mathrm{C}_{\mathrm{eq}} 1 \mathrm{a}-\mathrm{c}$ and $\mathrm{C}_{\mathrm{eq}} \mathrm{TS} 1 \mathrm{a}-\mathrm{c}$ are 10.3, 10.9, and $9.1 \mathrm{kcal} / \mathrm{mol}$ ). On the other hand, the activation Gibbs energy barriers of $\mathrm{C}_{\mathrm{ax}}$ TS1a, $\mathrm{C}_{\mathrm{ax}}$ TS1b and $\mathrm{C}_{\mathrm{ax}} \mathrm{TS} 1 \mathrm{c}$ are $8.2,8.3$, and $7.6 \mathrm{kcal} / \mathrm{mol}$, respectively. The distances of C1-O4 in $\mathrm{C}_{\mathrm{eq}} \mathrm{TS} 1 \mathrm{a}, \mathrm{C}_{\mathrm{eq}} \mathrm{TS} 1 \mathrm{~b}$ and $\mathrm{C}_{\mathrm{eq}} \mathrm{TS} 1 \mathrm{c}$ are $1.923,1.921$, and $1.886 \AA$, while they are $1.768,1.769$, and $1.715 \AA$ in $\mathrm{C}_{\mathrm{ax}}$ TS1a, $\mathrm{C}_{\mathrm{ax}} \mathrm{TS} 1 \mathrm{~b}$ and $\mathrm{C}_{\mathrm{ax}}$ TS1c. The shorter distances of $\mathrm{C} 1-\mathrm{O} 4$ in $\mathrm{C}_{\mathrm{eq}} \mathrm{TS} 1 \mathrm{c}$ and $\mathrm{C}_{\mathrm{ax}}$ TS1c are probably due to the steric congestion imposed by the isopropyl groups. The benzoxide insertion steps which give the products of $\mathrm{C}_{\mathrm{eq}} 2 \mathrm{a}-\mathrm{c}$ (Route 1) and $\mathrm{C}_{\mathrm{ax}} 2 \mathrm{a}-\mathrm{c}$ (Route 2) were evaluated as endergonic reactions. Noteworthily, the $\mathrm{L}^{i \mathrm{Pr}}$ systems of both routes require least input of energies to proceed the insertion step, probably because of the release of crowded space with the benzoxide group approaching to the $\varepsilon$-caprolactone [77]. The distances between $\mathrm{Al}$ and $\mathrm{O} 4$ of the inserted benzoxide in $\mathrm{C}_{\mathrm{eq}} 2 \mathrm{a}-\mathrm{c}$ are similar $(2.141,2.148$, and $2.147 \AA$ for $\mathrm{C}_{\mathrm{eq}} 2 \mathrm{a}, \mathrm{C}_{\mathrm{eq}} 2 \mathrm{~b}$ and $\left.\mathrm{C}_{\mathrm{eq}} 2 \mathrm{c}\right)$, while the aforementioned distance in $\mathrm{C}_{\mathrm{ax}} 2 \mathrm{c}(2.047 \AA)$ is longer than those in $\mathrm{C}_{\mathrm{ax}} 2 \mathrm{a}(2.021 \AA)$ and $\mathrm{C}_{\mathrm{ax}} 2 \mathrm{~b}(2.015 \AA)$. After the benzoxide insertion, the Al-O2 bond in $\mathrm{C}_{\mathrm{eq}} 2 \mathrm{a}-\mathrm{c} / \mathrm{C}_{\mathrm{ax}} 2 \mathrm{a}-\mathrm{c}$ rotates to yield $\mathrm{C}_{\mathrm{eq}} 3 \mathrm{a}-\mathrm{c} / \mathrm{C}_{\mathrm{ax}} 3 \mathrm{a}-\mathrm{c}$, which hold the structures in proper orientations to facilitate the $\mathrm{C} 1-\mathrm{O} 3$ bond breaking. Although $\mathrm{C}_{\mathrm{eq}} 2 \mathrm{a}-\mathrm{c} / \mathrm{C}_{\mathrm{eq}} 3 \mathrm{a}-\mathrm{c}$ and $\mathrm{C}_{\mathrm{ax}} 2 \mathrm{a}-\mathrm{c} / \mathrm{C}_{\mathrm{ax}} 3 \mathrm{a}-\mathrm{c}$ can be viewed as two pairs of linkage isomers, the computing result showed that the free energy differences between $\mathrm{C}_{\mathrm{eq}} 3 \mathrm{a}-\mathrm{c} / \mathrm{C}_{\mathrm{ax}} 3 \mathrm{a}-\mathrm{c}$ and $\mathrm{C}_{\mathrm{eq}} 2 \mathrm{a}-\mathrm{c} / \mathrm{C}_{\mathrm{ax}} 2 \mathrm{a}-\mathrm{c}$ are very dependent on their configurations and substituents. For the less bulky $\mathrm{L}$ and $\mathrm{L}^{\mathrm{Cl}}$ ligand systems, the free energies of $\mathrm{C}_{\mathrm{eq}} 3 \mathrm{a}-\mathrm{b}$ and $\mathrm{C}_{\mathrm{ax}} \mathrm{3a}-\mathrm{b}$ are more favored than those of $\mathrm{C}_{\mathrm{eq}} 2 \mathrm{a}-\mathrm{b}$ and $\mathrm{C}_{\mathrm{ax}} 2 \mathrm{a}-\mathrm{b}$ with around 3 and $6.5 \mathrm{kcal} / \mathrm{mol}$, respectively. For the $\mathrm{L}^{i P r}$ ligand systems, $3.1 \mathrm{kcal} / \mathrm{mol}$ is required to drive $\mathrm{C}_{\mathrm{eq}} 2 \mathrm{c}$ to $\mathrm{C}_{\mathrm{eq}} 3 \mathrm{c}$, while the pathway from $\mathrm{C}_{\mathrm{ax}} 2 \mathrm{c}$ to $\mathrm{C}_{\mathrm{ax}} 3 \mathrm{c}$ is exergonic by $3.7 \mathrm{kcal} / \mathrm{mol}$. Al and O3 are separated with the distance of 2.087, 2.082, and $2.092 \AA$ in $\mathrm{C}_{\mathrm{eq}} 3 \mathrm{a}, \mathrm{C}_{\mathrm{eq}} 3 \mathrm{~b}$, and $\mathrm{C}_{\mathrm{eq}} 3 \mathrm{c}$ and 2.113, 2.123, and $2.123 \AA$ in $\mathrm{C}_{\mathrm{ax}} 3 \mathrm{a}, \mathrm{C}_{\mathrm{ax}} 3 \mathrm{~b}$, and $\mathrm{C}_{\mathrm{ax}} 3 \mathrm{c}$. The distances reveal the $\mathrm{Al} \ldots \mathrm{O} 3$ interaction in $\mathrm{C}_{\mathrm{eq}} 3 \mathrm{a}-\mathrm{c} / \mathrm{C}_{\mathrm{ax}} 3 \mathrm{a}-\mathrm{c}$, driving the $\mathrm{C} 1-\mathrm{O} 3$ bond cleavage to complete 
the ring opening. $\mathrm{C}_{\mathrm{eq}} \mathrm{TS} 2 \mathrm{a}-\mathrm{c}$ and $\mathrm{C}_{\mathrm{ax}} \mathrm{TS} 2 \mathrm{a}-\mathrm{c}$ represent the possible transition-state structures for the ring-opening steps. The C1-O3 are elongated to $1.924,1.932$, and $1.898 \AA$ in $\mathrm{C}_{\text {eq }}$ TS2a, $\mathrm{C}_{\text {eq }} \mathrm{TS} 2 \mathrm{~b}$, and $\mathrm{C}_{\mathrm{eq}}$ TS2c. The corresponding distances in $\mathrm{C}_{\mathrm{ax}}$ TS2a, $\mathrm{C}_{\mathrm{ax}}$ TS2b, and $\mathrm{C}_{\mathrm{ax}}$ TS2c are 1.932, 1.922, and $1.781 \AA$. The reactions then generate the final products $C_{e q} 4 a-c$ and $C_{a x} 4 a-c$ by conquering small energy barriers of $\sim 2$ (Route 1 ) and $\sim 0.5-5$ (Route 2 ) $\mathrm{kcal} / \mathrm{mol}$, respectively. In $\mathrm{C}_{\mathrm{eq}} 4 \mathrm{a}-\mathrm{c}$ and $\mathrm{C}_{\mathrm{ax}} 4 \mathrm{a}-\mathrm{c}$, the $\mathrm{C} 1-\mathrm{O} 3$ of $\varepsilon$-caprolactone has been broken and reformed to a nine-membered ring with Al. Consequently, the coordination-insertion ring-opening reactions are slightly endergonic by less than $2 \mathrm{kcal} / \mathrm{mol}$ in both routes of $\mathrm{L}$ and $\mathrm{L}^{\mathrm{Cl}}$ system. For the cases of $\mathrm{L}^{i \mathrm{Pr}}$ systems, Route 1 is predicted to be $3.6 \mathrm{kcal} / \mathrm{mol}$ endergonic, whereas Route 2 is $1.8 \mathrm{kcal} / \mathrm{mol}$ exergonic.

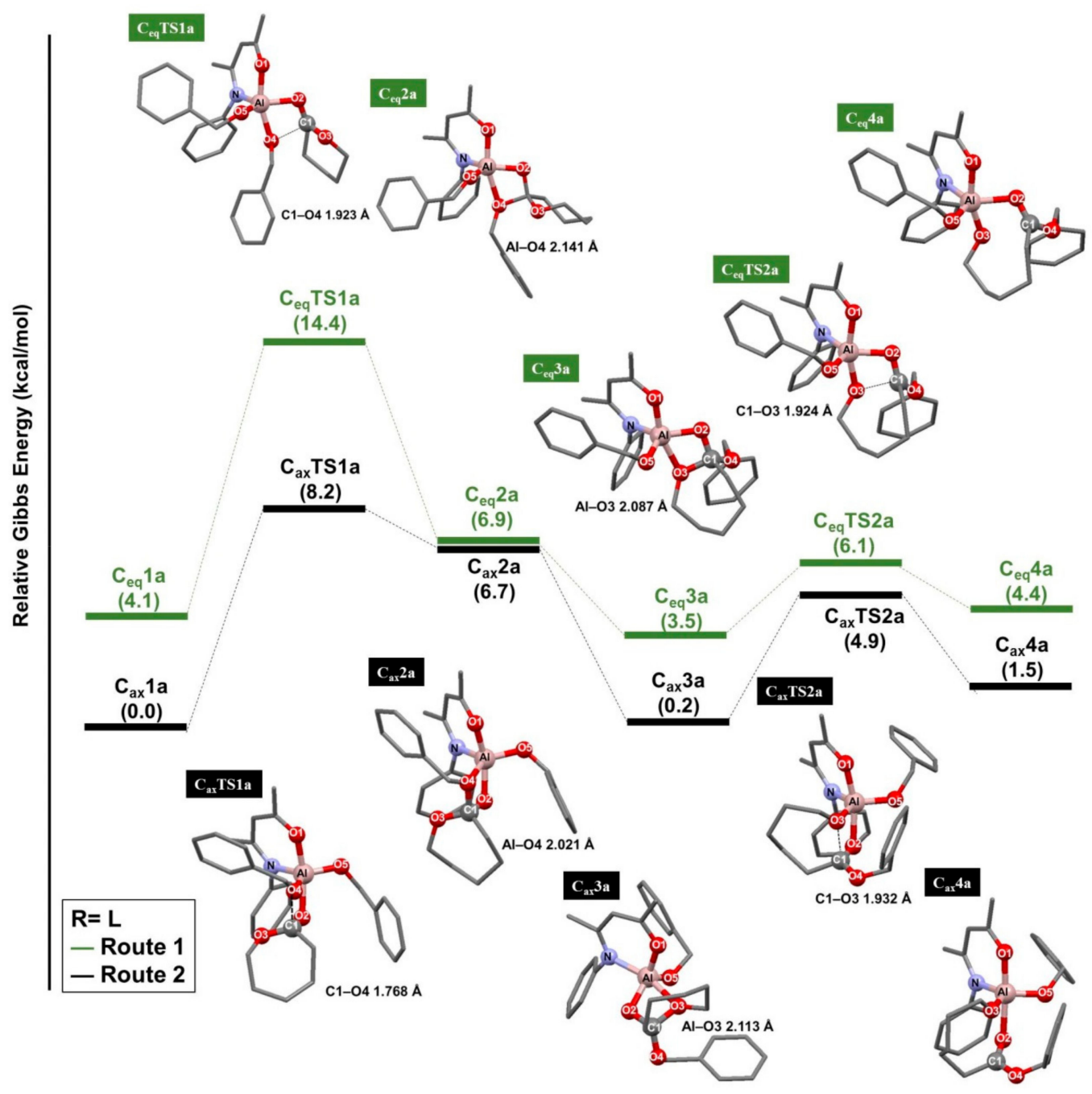

Figure 5. Reaction profile and optimized structures of the L system. (Monomer: $\varepsilon$-caprolactone). 


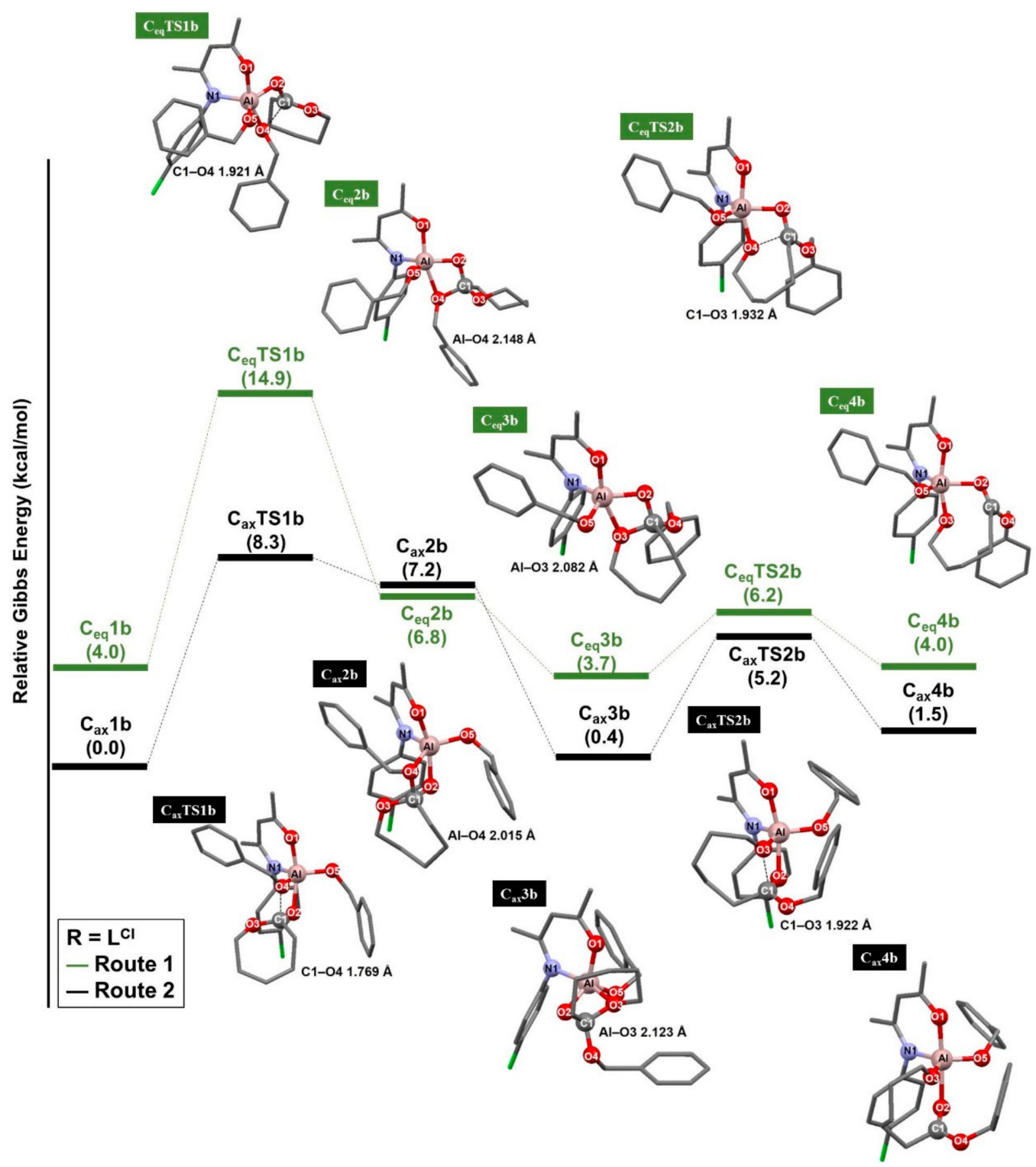

Figure 6. Reaction profile and optimized structures of the $\mathrm{L}^{\mathrm{Cl}}$ system. (Monomer: $\varepsilon$-caprolactone). 


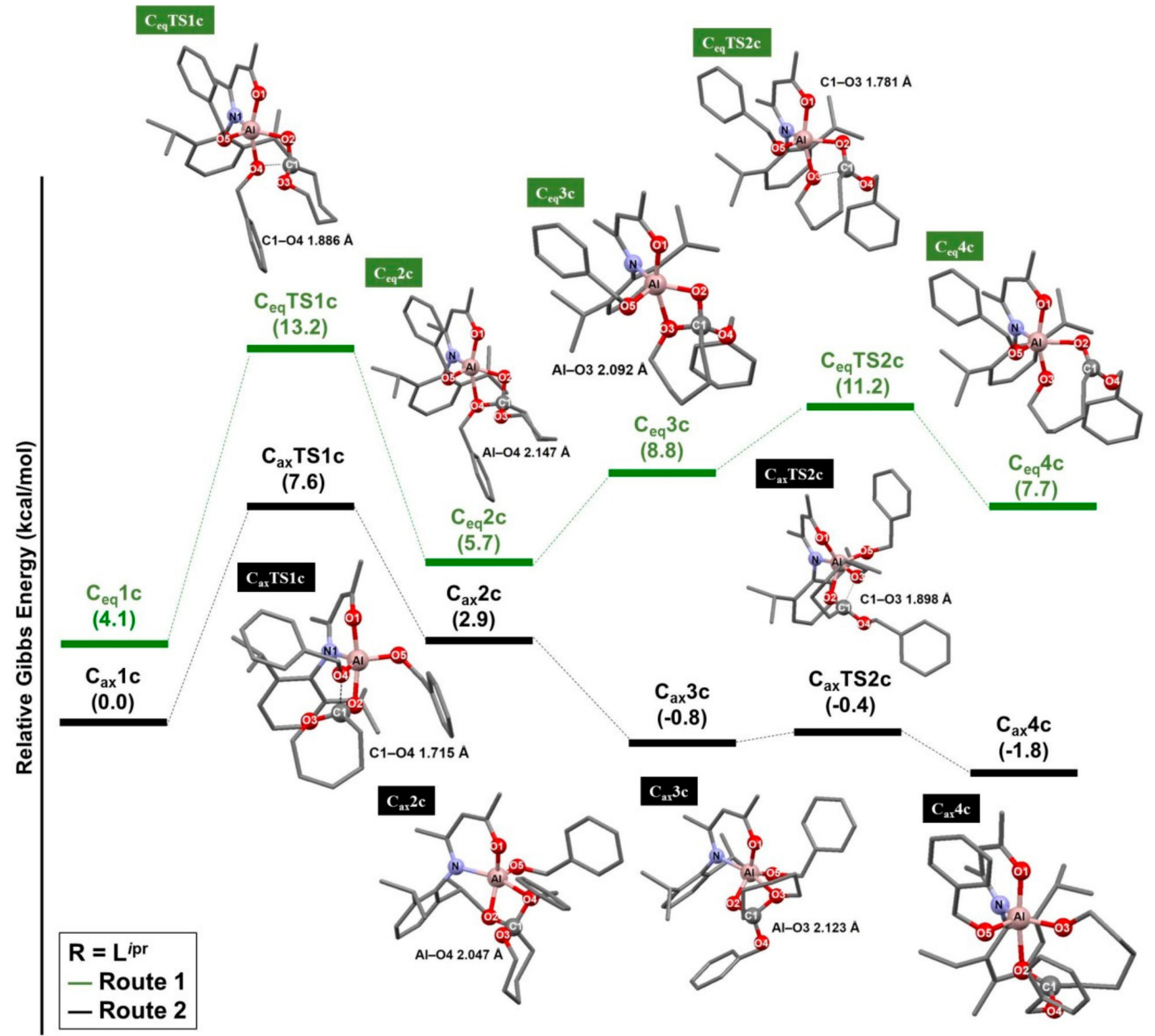

Figure 7. Reaction profile and optimized structures of the $\mathrm{L}^{i \mathrm{Pr}}$ system. (Monomer: $\varepsilon$-caprolactone).

Comparing the reaction barriers, Route 2 requires much lower free energy than Route 1 to make the reaction take place, indicating that coordination of $\varepsilon$-caprolactone in the axial position is the better direction to undergo nucleophilic addition. The corresponding structures of the transition states in Route 2 display a C1 ... O 4 distance about $1.75 \AA$, shorter than those in Route 1 (about $1.92 \AA$ ). The shorter distance of $\mathrm{C} 1 \ldots \mathrm{O} 4$ in Route 2 also supports the fact that the benzoxide fragment can attack the carbonyl group of $\varepsilon$-caprolactone more effectively. As a result, Route 2 is a preferential pathway for the ring-opening polymerization of $\varepsilon$-caprolactone. Moreover, the activation barriers in the $\mathrm{L}^{\mathrm{ipr}}$ system is about $1 \mathrm{kcal} / \mathrm{mol}$ smaller than those in the $\mathrm{L}$ and $\mathrm{L}^{\mathrm{Cl}}$ systems, in consistency with the experimental results. It can be attributed to the sterically encumbered groups obliging the benzoxide fragment to get closer to the $\varepsilon$-caprolactone thus speeding up the occurrence of the insertion step, which determines the rate of the ring-opening polymerization of $\varepsilon$-caprolactone.

\subsection{Ring-Opening Polymerization of L-Lactide}

The ring-opening polymerization mechanism of $L$-lactide shows different characteristics compared to $\varepsilon$-caprolactone polymerization. Although $L$-lactide can approach the $\mathrm{Al}$ center from the equatorial site, the results of the scan calculation show that benzoxide cannot attack the carbonyl group from this orientation. Hence, Route 2 is the only possible pathway for the ring-opening polymerization of L-lactide. The Al-O2 (Al-O $\mathrm{LA}_{\mathrm{LA}}$ ) bond lengths of $\mathrm{L}_{\mathrm{ax}} 1 \mathrm{a}, \mathrm{L}_{\mathrm{ax}} 1 \mathrm{~b}$, and $\mathrm{L}_{\mathrm{ax}} 1 \mathrm{c}$ are 2.091, 2.072, and $2.099 \AA$, respectively (Figure 8). The values are slightly longer than those in $C_{a x} 1 a-c$, probably because of the bulkier monomer of $L$-lactide. The bond enthalpies of $\mathrm{Al}-\mathrm{O} 2$ in $\mathrm{Lax} 1 \mathrm{a}-\mathrm{c}$ are calculated to be larger than those in $\mathrm{C}_{\mathrm{ax}} 1 \mathrm{a}-\mathrm{c}\left(\mathrm{L}_{\mathrm{ax}} 1 \mathrm{a}:-12.6 \mathrm{kcal} / \mathrm{mol} ; \mathrm{L}_{\mathrm{ax}} 1 \mathrm{~b}:-13.9 \mathrm{kcal} / \mathrm{mol} ; \mathrm{L}_{\mathrm{ax}} 1 \mathrm{c}:-12.3 \mathrm{kcal} / \mathrm{mol}\right)$. Among these 
species, the electron withdrawing inductive effect in $\mathrm{L}_{\mathrm{ax}} 1 \mathrm{~b}$ would lead to the more stable $\mathrm{Al}-\mathrm{O} 2$ bond. Nevertheless, the calculation result in $\mathrm{L}_{\mathrm{ax}} 1 \mathrm{c}$ implies that the steric hindrance does not exhibit obvious influence on the $\mathrm{Al}-\mathrm{O} 2$ bond enthalpy.
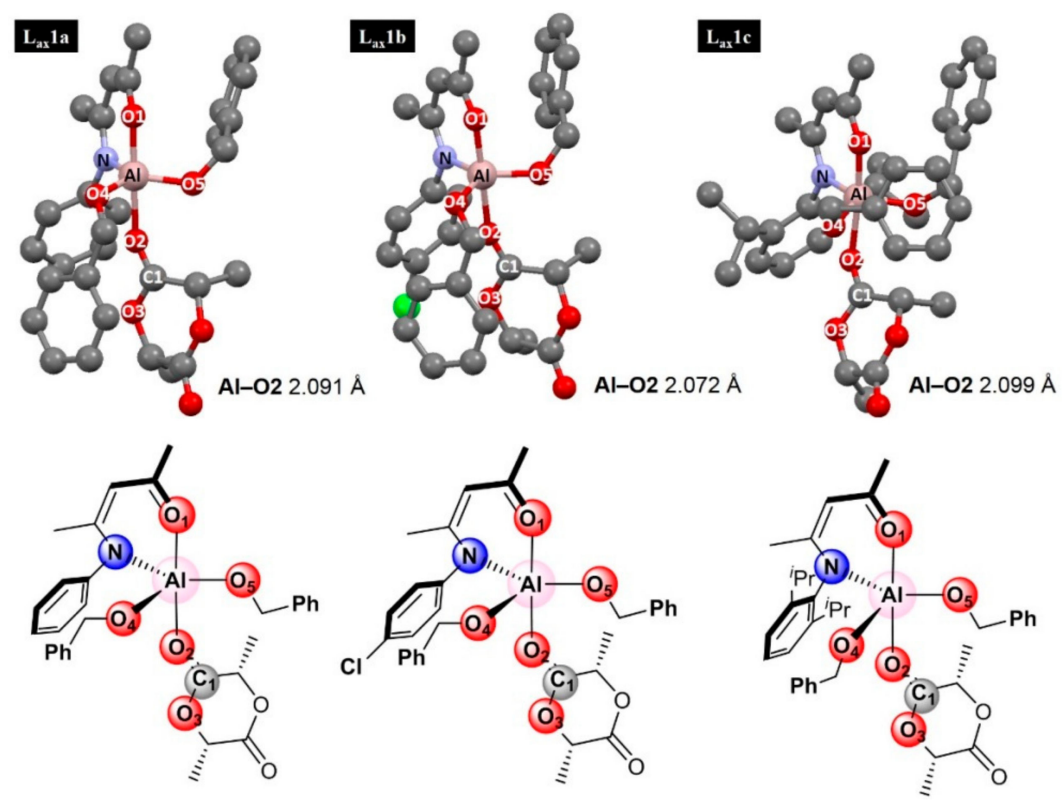

Figure 8. L-lactide coordinated aluminum complexes which bear $\mathrm{L}, \mathrm{L}^{\mathrm{Cl}}$, and $\mathrm{L}^{\mathrm{iPr}}$ ligand systems and arrange in a TBP fashion.

DFT calculated Gibbs energy profiles of the proposed mechanism for the $\mathrm{L}_{\mathrm{ax}} 1 \mathrm{a}-\mathrm{c}$ catalyzed ring-opening polymerization of L-lactide are shown in Figures 9-11. Different from the case of $\varepsilon$-caprolactone, the cleavage of the $\mathrm{C}-\mathrm{O}$ bond is the rate-determining step in the ring-opening polymerization of L-lactide. The activation barriers generated from the nucleophilic addition of benzoxide to the carbonyl group on the L-lactide are about $7 \mathrm{kcal} / \mathrm{mol}$, similar to the case of the ring-opening polymerization of $\varepsilon$-caprolactone. The corresponding transition states are determined to be a distorted square pyramidal structure, and the $\mathrm{C} 1$... O 4 distances are separated by $1.934 \AA$ in $\mathrm{L}_{a x} \mathrm{TS1a}, 1.932 \AA$ in $\mathrm{L}_{\mathrm{ax}} \mathrm{TS} 1 \mathrm{~b}$, and $1.869 \AA$ in $\mathrm{L}_{\mathrm{ax}} \mathrm{TS} 1 \mathrm{c}$. The bulky pendant groups in $\mathrm{L}_{a x}$ TS1c would lead to confined space and therefore result in the shorter $\mathrm{C} 1 \ldots$ O 4 distance. The intermediates produced from the insertion step are the species $\mathrm{L}_{\mathrm{ax}} 2 \mathrm{a}-\mathrm{c}$ with $\mathrm{Al} \ldots \mathrm{O} 4$ distances of 2.149, 2.135, and $2.195 \AA$ in $\mathrm{L}_{\mathrm{ax}} 2 \mathrm{a}, \mathrm{L}_{\mathrm{ax}} 2 \mathrm{~b}$, and $\mathrm{L}_{\mathrm{ax}} 2 \mathrm{c}$, respectively. $\mathrm{L}_{\mathrm{ax}} 2 \mathrm{a}-\mathrm{c}$ then undergo a bond rotation and yield $\mathrm{L}_{\mathrm{ax}} 3 \mathrm{a}-\mathrm{c}$, the conformations more suitable for $\mathrm{C}-\mathrm{O}$ cleavage. Compared to $\mathrm{L}_{\mathrm{ax}} 2 \mathrm{a}-\mathrm{c}$, the $\mathrm{Al} \ldots \mathrm{O} 3$ distances in $\mathrm{L}_{\mathrm{ax}} 3 \mathrm{a}-\mathrm{c}$ are shortened while $\mathrm{C} 1-\mathrm{O} 4$ bonds are elongated. Noteworthily, the $\mathrm{Al} \ldots \mathrm{O} 3$ distance in $\mathrm{L}_{\mathrm{ax}} 3 \mathrm{c}$ (2.342 $\AA$ ) is much longer than in $\mathrm{L}_{\mathrm{ax}} 3 \mathrm{a}(2.215 \AA)$ and $\mathrm{L}_{\mathrm{ax}} 3 \mathrm{~b}(2.174 \AA)$. The breakage of the $\mathrm{C} 1-\mathrm{O} 3$ bond involves the transition states $\mathrm{L}_{\mathrm{ax}}$ TS2a-c which lie 12.1, 11.6, and $15.1 \mathrm{kcal} / \mathrm{mol}$ above $\mathrm{L}_{\mathrm{ax}} 3 \mathrm{a}, \mathrm{L}_{\mathrm{ax}} 3 \mathrm{~b}$, and $\mathrm{L}_{\mathrm{ax}} 3 \mathrm{c}$, respectively. The highest potential Gibbs energies of $\mathrm{L}_{\mathrm{ax}} \mathrm{TS} 2 \mathrm{a}-\mathrm{c}$ reveal the $\mathrm{C} 1-\mathrm{O} 3$ breaking step determines the rate of the ring opening polymerization of L-lactide. The calculation results show that the C1-O3 distances are 2.002, 2.001, and $2.069 \AA$ in Lax TS2a, Lax TS2b, and Lax TS2c, respectively. Following the intrinsic reaction coordinate, $\mathrm{L}_{\mathrm{ax}} \mathrm{TS} 2 \mathrm{a}-\mathrm{c}$ give rise to the unstable intermediates $\mathrm{L}_{\mathrm{ax}} 4 \mathrm{a}-\mathrm{c}$ which are better described as a distorted tetrahedral species. Finally, $\mathrm{L}_{\mathrm{ax}} 4 \mathrm{a}-\mathrm{c}$ rearrange to the conformations of $\mathrm{L}_{\mathrm{ax}} 5 \mathrm{a}-\mathrm{c}$, which adopt a TBP structure with the bidentate coordination of the ring-open L-lactide moiety. 


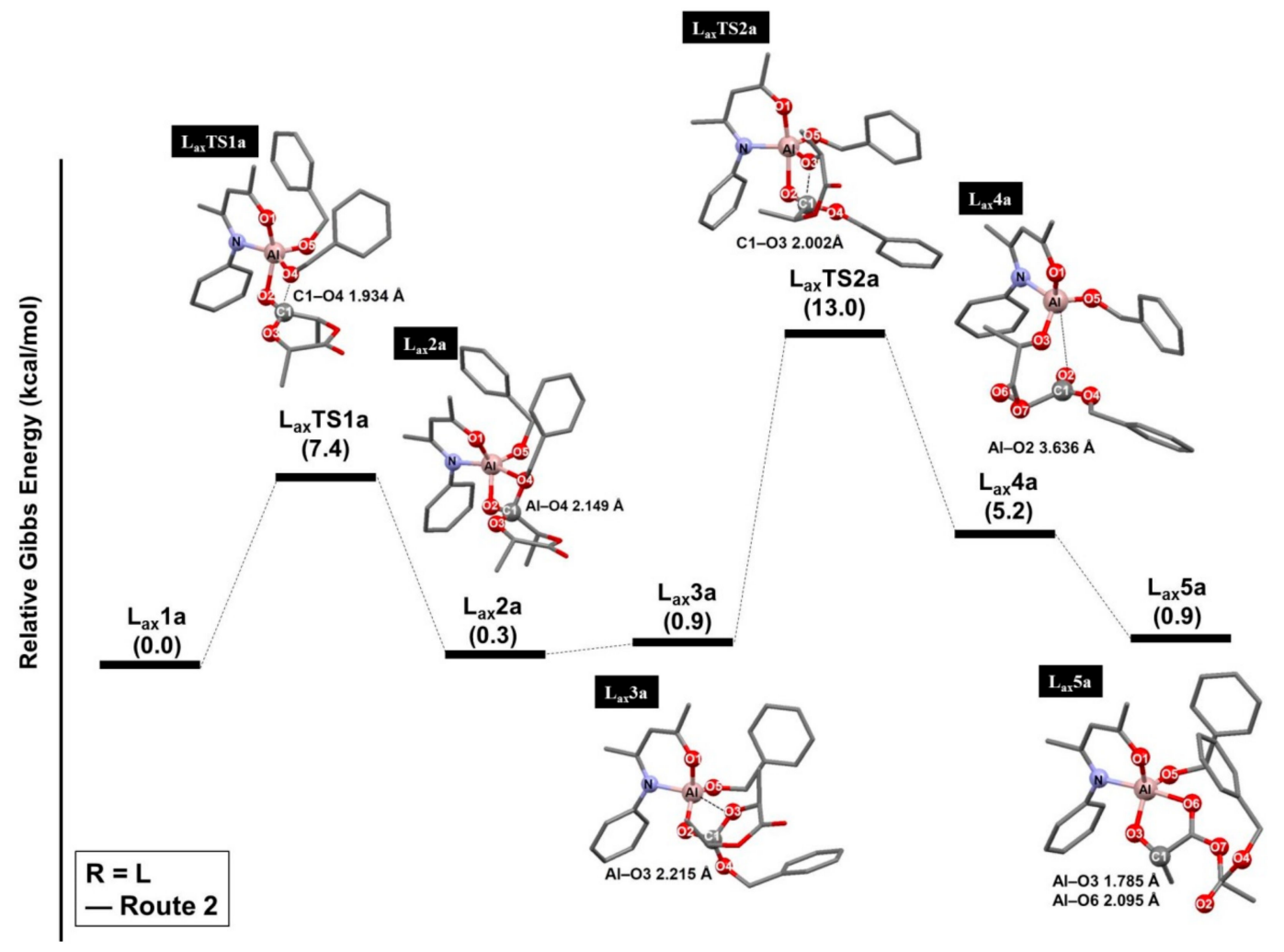

Figure 9. Reaction profile and optimized structures of the L system. (Monomer: L-lactide).

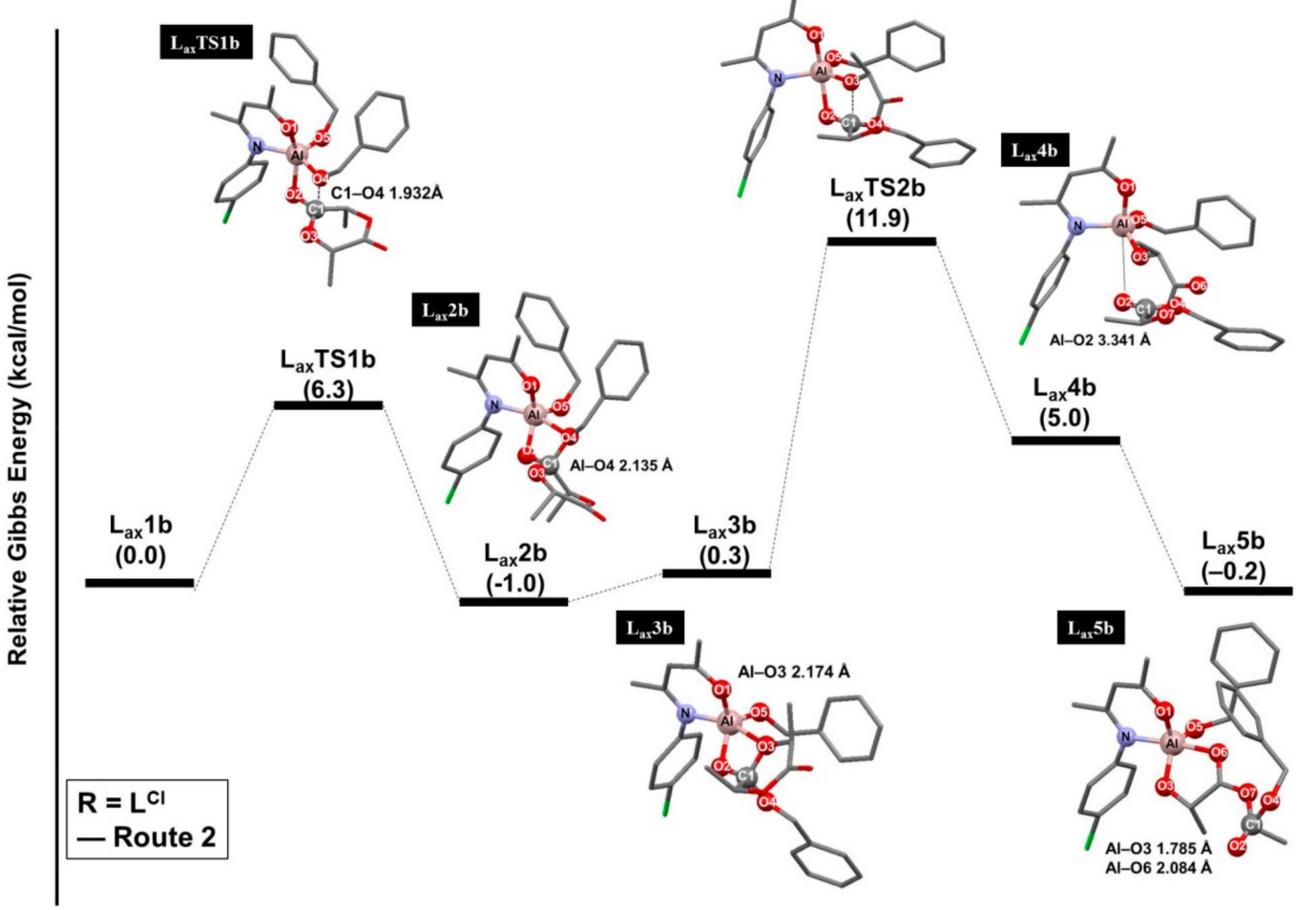

Figure 10. Reaction profile and optimized structures of the $\mathrm{L}^{\mathrm{Cl}}$ system. (Monomer: L-lactide). 


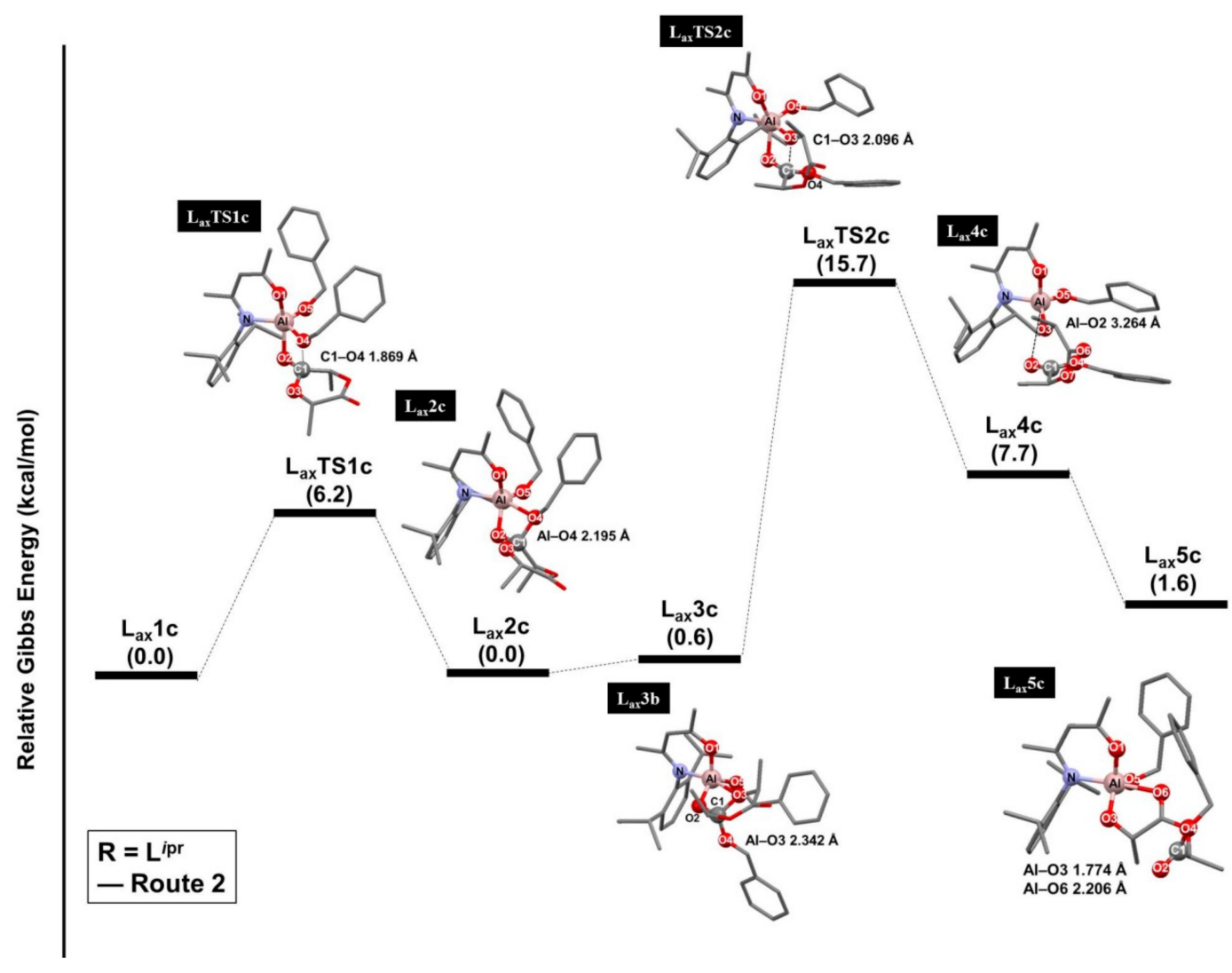

Figure 11. Reaction profile and optimized structures of the $L^{i \operatorname{Pr}}$ system. (Monomer: $L$-lactide).

The theoretical prediction shows that the $\mathrm{L}^{\mathrm{iPr}}$ system has the largest activation barrier among the three catalysts. Therefore, it would initiate the ring-opening polymerization of L-lactide more slowly, in agreement with the experimental results. The reaction is rate-determined by the ring opening step, the produced fragment of which would occupy more space. As a consequence, the reaction will be retarded by the bulky substituents. On the other hand, the reaction barriers of the ring-opening polymerization of $L$-lactide are estimated to be about twice larger than those of $\varepsilon$-caprolactone. The computational results have elucidated the fact that the ring-opening polymerization of $L$-lactide need to proceed at higher temperature in comparison to the case of $\varepsilon$-caprolactone.

\section{Conclusions}

In this study, we have shown that the ring-opening polymerization of $\varepsilon$-caprolactone is rate-determined by the step of benzoxide insertion, while the bond cleavage step is the slowest step in the case of ring-opening polymerization of L-lactide. Besides, theoretical analysis revealed that the reaction barriers of the ring-opening polymerization of L-lactide are higher than those of $\varepsilon$-caprolactone, corresponding to the experimental results. Finally, the pendant groups on the ketiminate ligand of the aluminum complexes play an essential role in catalyzing the ring-opening polymerization. In the $\varepsilon$-caprolactone ring-opening polymerization system, the crucial transition state is the stage benzoxide attacking the caprolactone. When the ketimate ligand bears more bulky groups, the congestion can be more largely released. Consequently, the reaction barrier is lowered to facilitate the occurrence of insertion when the pendant groups are more bulky. On the contrary, when L-lactides are loaded as monomers, the aluminum complexes supported by bulky groups are not conducive to the ring-opening polymerization. Since the rate-determining step of bond cleavage would lead to the occupation of space, the bulky substituents would go against the reaction to prevent from losing space. The calculation results are in agreement with the experimental data. 
Supplementary Materials: The optimized structures involved in this study are available online at http://www. mdpi.com/2073-4360/11/9/1530/s1, Table S1: Cartesian coordinate of Ceq1a, Table S2: Cartesian coordinate of CeqTS1a, Table S3: Cartesian coordinate of Ceq2a, Table S4: Cartesian coordinate of Ceq3a, Table S5: Cartesian coordinate of CeqTS2a, Table S6: Cartesian coordinate of Ceq4a, Table S7: Cartesian coordinate of Cax1a, Table S8: Cartesian coordinate of CaxTS1a, Table S9: Cartesian coordinate of Cax2a, Table S10: Cartesian coordinate of Cax3a, Table S11: Cartesian coordinate of CaxTS2a, Table S12: Cartesian coordinate of Cax4a, Table S13: Cartesian coordinate of Ceq1b, Table S14: Cartesian coordinate of CeqTS1b, Table S15: Cartesian coordinate of Ceq2b, Table S16: Cartesian coordinate of Ceq3b, Table S17: Cartesian coordinate of CeqTS2b, Table S18: Cartesian coordinate of Ceq5b, Table S19: Cartesian coordinate of Cax1b, Table S20: Cartesian coordinate of CaxTS1b, Table S21: Cartesian coordinate of Cax2b, Table S22: Cartesian coordinate of Cax3b, Table S23: Cartesian coordinate of CaxTS2b, Table S24: Cartesian coordinate of Cax4b, Table S25: Cartesian coordinate of Ceq1c, Table S26: Cartesian coordinate of CeqTS1c, Table S27: Cartesian coordinate of Ceq2c, Table S28: Cartesian coordinate of Ceq3c, Table S29: Cartesian coordinate of CeqTS2c, Table S30: Cartesian coordinate of Ceq4c, Table S31: Cartesian coordinate of Cax1c, Table S32: Cartesian coordinate of CaxTS1c, Table S33: Cartesian coordinate of Cax2c, Table S34: Cartesian coordinate of Cax3c, Table S35: Cartesian coordinate of CaxTS2c, Table S36: Cartesian coordinate of Cax4c, Table S37: Cartesian coordinate of Lax1a, Table S38: Cartesian coordinate of LaxTS1a, Table S39: Cartesian coordinate of Lax2a, Table S40: Cartesian coordinate of Lax3a, Table S41: Cartesian coordinate of LaxTS2a, Table S42: Cartesian coordinate of Lax4a, Table S43: Cartesian coordinate of Lax5a, Table S44: Cartesian coordinate of Lax1b, Table S45: Cartesian coordinate of LaxTS1b, Table S46: Cartesian coordinate of Lax2b, Table S47: Cartesian coordinate of Lax3b, Table S48: Cartesian coordinate of LaxTS2b, Table S49: Cartesian coordinate of Lax4b, Table S50: Cartesian coordinate of Lax5a, Table S51: Cartesian coordinate of Lax1c, Table S52: Cartesian coordinate of LaxTS1c, Table S53: Cartesian coordinate of Lax2c, Table S54: Cartesian coordinate of Lax3c, Table S55: Cartesian coordinate of LaxTS2c, Table S56: Cartesian coordinate of Lax4c, Table S57: Cartesian coordinate of Lax 5 c.

Author Contributions: Conceptualization, Y.-F.L.; methodology, Y.-F.L.; Calculation, Y.-F.L.; Visualization, Y.-F.L.; Writing-review and editing, Y.-F.L.; Supervision, Y.-F.L.; Calculation, N.Y.-J.

Funding: This research was funded by the Ministry of Science and Technology (MOST), grant number MOST 106-2113-M-037-007 and MOST 107-2113-M-037-005-MY2.

Conflicts of Interest: The authors declare no conflict of interest.

\section{References}

1. Chiellini, E.; Solaro, R. Biodegradable Polymeric Materials. Adv. Mater. 1996, 8, 305-313. [CrossRef]

2. Drumright, R.E.; Gruber, P.R.; Henton, D.E. Polylactic Acid Technology. Adv. Mater. 2000, 12, $1841-1846$. [CrossRef]

3. Albertsson, A.-C.; Varma, I.K. Recent Developments in Ring Opening Polymerization of Lactones for Biomedical Applications. Biomacromolecules 2003, 4, 1466-1486. [CrossRef] [PubMed]

4. Auras, R.; Harte, B.; Selke, S. An Overview of Polylactides as Packaging Materials. Macromol. Biosci. 2004, 4, 835-864. [CrossRef] [PubMed]

5. Faÿ, F.; Renard, E.; Langlois, V.; Linossier, I.; Vallée-Rehel, K. Development of Poly( $\varepsilon$-caprolactone-co-l-lactide) and Poly ( $\varepsilon$-caprolactone-co- $\delta$-valerolactone) as New Degradable Binder Used for Antifouling Paint. Eur. Polym. J. 2007, 43, 4800-4813. [CrossRef]

6. Slomkowski, S.; Penczek, S.; Duda, A. Polylactides-an Overview. Polym. Adv. Technol. 2014, 25, 436-447. [CrossRef]

7. Nomura, N.; Ishii, R.; Akakura, M.; Aoi, K. Stereoselective Ring-Opening Polymerization of Racemic Lactide Using Aluminum-Achiral Ligand Complexes: Exploration of a Chain-End Control Mechanism. J. Am. Chem. Soc. 2002, 124, 5938-5939. [CrossRef]

8. Zhong, Z.; Dijkstra, P.J.; Feijen, J. [(salen)Al]-Mediated, Controlled and Stereoselective Ring-Opening Polymerization of Lactide in Solution and without Solvent: Synthesis of Highly Isotactic Polylactide Stereocopolymers from Racemic d,1-Lactide. Angew. Chem. Int. Ed. 2002, 41, 4510-4513. [CrossRef]

9. Alcazar-Roman, L.M.; O'Keefe, B.J.; Hillmyer, M.A.; Tolman, W.B. Electronic Influence of Ligand Substituents on The Rate of Polymerization of $\varepsilon$-Caprolactone by Single-Site Aluminium Alkoxide Catalysts. Dalton Trans 2003, 3082-3087. [CrossRef]

10. Hormnirun, P.; Marshall, E.L.; Gibson, V.C.; White, A.J.P.; Williams, D.J. Remarkable Stereocontrol in the Polymerization of Racemic Lactide Using Aluminum Initiators Supported by Tetradentate Aminophenoxide Ligands. J. Am. Chem. Soc. 2004, 126, 2688-2689. [CrossRef]

11. Ishii, R.; Nomura, N.; Kondo, T. Stereoselective Bulk Polymerization of Racemic Lactide for Stereoblock Poly(racemic lactide) Using an Achiral Aluminum Complex. Polym. J. 2004, 36, 261-264. [CrossRef] 
12. Hormnirun, P.; Marshall, E.L.; Gibson, V.C.; Pugh, R.I.; White, A.J.P. Study of Ligand Substituent Effects on the Rate and Stereoselectivity of Lactide Polymerization Using Aluminum Salen-Type Initiators. Proc. Natl. Acad. Sci. USA 2006, 103, 15343-15348. [CrossRef] [PubMed]

13. Nomura, N.; Ishii, R.; Yamamoto, Y.; Kondo, T. Stereoselective Ring-Opening Polymerization of a Racemic Lactide by Using Achiral Salen and Homosalen-Aluminum Complexes. Chem. Eur. J. 2007, 13, 4433-4451. [CrossRef] [PubMed]

14. Chisholm, M.H.; Gallucci, J.C.; Quisenberry, K.T.; Zhou, Z. Complexities in the Ring-Opening Polymerization of Lactide by Chiral Salen Aluminum Initiators. Inorg. Chem. 2008, 47, 2613-2624. [CrossRef] [PubMed]

15. Shen, M.; Zhang, W.; Nomura, K.; Sun, W.-H. Synthesis and Characterization of Organoaluminum Compounds Containing Quinolin-8-amine Derivatives and Their Catalytic Behaviour for Ring-Opening Polymerization of $\varepsilon$-Caprolactone. Dalton Trans. 2009, 41, 9000-9009. [CrossRef]

16. Darensbourg, D.J.; Karroonnirun, O. Stereoselective Ring-Opening Polymerization of rac-Lactides Catalyzed by Chiral and Achiral Aluminum Half-Salen Complexes. Organometallics 2010, 29, 5627-5634. [CrossRef]

17. Sun, W.-H.; Shen, M.; Zhang, W.; Huang, W.; Liu, S.; Redshaw, C. Methylaluminium 8-quinolinolates: Synthesis, characterization and use in ring-opening polymerization (ROP) of $\varepsilon$-caprolactone. Dalton Trans. 2011, 40, 2645-2653. [CrossRef]

18. Whitelaw, E.L.; Loraine, G.; Mahon, M.F.; Jones, M.D. Salalen Aluminium Complexes and their Exploitation for the Ring Opening Polymerisation of rac-Lactide. Dalton Trans. 2011, 40, 11469-11473. [CrossRef]

19. Bakewell, C.; Platel, R.H.; Cary, S.K.; Hubbard, S.M.; Roaf, J.M.; Levine, A.C.; White, A.J.P.; Long, N.J.; Haaf, M.; Williams, C.K. Bis(8-quinolinolato)aluminum ethyl Complexes: Iso-Selective Initiators for rac-Lactide Polymerization. Organometallics 2012, 31, 4729-4736. [CrossRef]

20. Chen, H.-L.; Dutta, S.; Huang, P.-Y.; Lin, C.-C. Preparation and Characterization of Aluminum Alkoxides Coordinated on salen-Type Ligands: Highly Stereoselective Ring-Opening Polymerization of rac-Lactide. Organometallics 2012, 31, 2016-2025. [CrossRef]

21. Ikpo, N.; Barbon, S.M.; Drover, M.W.; Dawe, L.N.; Kerton, F.M. Aluminum Methyl and Chloro Complexes Bearing Monoanionic Aminephenolate Ligands: Synthesis, Characterization, and Use in Polymerizations. Organometallics 2012, 31, 8145-8158. [CrossRef]

22. Castro-Osma, J.A.; Alonso-Moreno, C.; Márquez-Segovia, I.; Otero, A.; Lara-Sánchez, A.; Fernández-Baeza, J.; Rodríguez, A.M.; Sánchez-Barba, L.F.; García-Martínez, J.C. Synthesis, Structural Characterization and Catalytic Evaluation of the Ring-Opening Polymerization of Discrete Five-Coordinate Alkyl Aluminium Complexes. Dalton Trans. 2013, 42, 9325-9337. [CrossRef] [PubMed]

23. Gao, B.; Duan, R.; Pang, X.; Li, X.; Qu, Z.; Tang, Z.; Zhuang, X.; Chen, X. Stereoselective Ring-Opening Polymerization of rac-Lactides Catalyzed by Aluminum Hemi-Salen Complexes. Organometallics 2013, 32, 5435-5444. [CrossRef]

24. Hancock, S.L.; Mahon, M.F.; Jones, M.D. Aluminium Salalen Complexes Based on 1,2-Diaminocyclohexane and their Exploitation for the Polymerisation of rac-Lactide. Dalton Trans. 2013, 42, 9279-9285. [CrossRef] [PubMed]

25. Liu, J.; Ma, H. Aluminum Complexes with Bidentate Amido Ligands: Synthesis, Structure and Performance on Ligand-Initiated Ring-Opening Polymerization of rac-Lactide. Dalton Trans. 2014, 43, 9098-9110. [CrossRef] [PubMed]

26. Zhang, W.; Wang, Y.; Wang, L.; Redshaw, C.; Sun, W.-H. Dialkylaluminium 2-Imidazolylphenolates: Synthesis, Characterization and Ring-Opening Polymerization Behavior Towards Lactides. J. Organomet. Chem. 2014, 750, 65-73. [CrossRef]

27. Tabthong, S.; Nanok, T.; Sumrit, P.; Kongsaeree, P.; Prabpai, S.; Chuawong, P.; Hormnirun, P. Bis(pyrrolidene) Schiff Base Aluminum Complexes as Isoselective-Biased Initiators for the Controlled Ring-Opening Polymerization of rac-Lactide: Experimental and Theoretical Studies. Macromolecules 2015, 48, 6846-6861. [CrossRef]

28. Fuoco, T.; Pappalardo, D. Aluminum Alkyl Complexes Bearing Salicylaldiminato Ligands: Versatile Initiators in the Ring-Opening Polymerization of Cyclic Esters. Catalysts 2017, 7, 64. [CrossRef]

29. Nakonkhet, C.; Nanok, T.; Wattanathana, W.; Chuawong, P.; Hormnirun, P. Aluminium Complexes Containing Salicylbenzothiazole Ligands and their Application in the Ring-Opening Polymerisation of rac-Lactide and $\varepsilon$-Caprolactone. Dalton Trans. 2017, 46, 11013-11030. [CrossRef] 
30. Huang, H.-C.; Wang, B.; Chen, X.-L.; Pan, L.; Li, Y.-S. Ring-Opening Polymerization of (Macro)lactones by Highly Active Mononuclear Salen-Aluminum Complexes Bearing Cyclic $\beta$-Ketoiminato Ligand. J. Polym. Sci. Polym. Chem. 2019, 57, 973-981. [CrossRef]

31. Kricheldorf, H.R.; Berl, M.; Scharnagl, N. Poly(lactones). 9. Polymerization Mechanism of Metal Alkoxide Initiated Polymerizations of Lactide and Various Lactones. Macromolecules 1988, 21, 286-293. [CrossRef]

32. Dubois, P.; Barakat, I.; Jerome, R.; Teyssie, P. Macromolecular Engineering of Polyactones and Polyactides. 12. Study of the Depolymerization Reactions of Poly(.epsilon-caprolactone) with Functional Aluminum Alkoxide end Groups. Macromolecules 1993, 26, 4407-4412. [CrossRef]

33. Yu, R.-C.; Hung, C.-H.; Huang, J.-H.; Lee, H.-Y.; Chen, J.-T. Four- and Five-Coordinate Aluminum Ketiminate Complexes: Synthesis, Characterization, and Ring-Opening Polymerization. Inorg. Chem. 2002, 41, 6450-6455. [CrossRef] [PubMed]

34. Tabthong, S.; Nanok, T.; Kongsaeree, P.; Prabpai, S.; Hormnirun, P. Monomethylaluminum and Dimethylaluminum Pyrrolylaldiminates for the Ring-Opening Polymerization of rac-Lactide: Effects of Ligand Structure and Coordination Geometry. Dalton Trans. 2014, 43, 1348-1359. [CrossRef] [PubMed]

35. Sumrit, P.; Chuawong, P.; Nanok, T.; Duangthongyou, T.; Hormnirun, P. Aluminum Complexes Containing Salicylbenzoxazole Ligands and their Application in the Ring-Opening Polymerization of rac-Lactide and $\varepsilon$-Caprolactone. Dalton Trans. 2016, 45, 9250-9266. [CrossRef]

36. Lee, C.-L.; Lin, Y.-F.; Jiang, M.-T.; Lu, W.-Y.; Vandavasi, J.K.; Wang, L.-F.; Lai, Y.-C.; Chiang, M.Y.; Chen, H.-Y. Improvement in Aluminum Complexes Bearing Schiff Bases in Ring-Opening Polymerization of $\varepsilon$-Caprolactone: A Five-Membered-Ring System. Organometallics 2017, 36, 1936-1945. [CrossRef]

37. Nomura, N.; Akita, A.; Ishii, R.; Mizuno, M. Random Copolymerization of $\varepsilon$-Caprolactone with Lactide Using a Homosalen-Al Complex. J. Am. Chem. Soc. 2010, 132, 1750-1751. [CrossRef] [PubMed]

38. Koller, J.; Bergman, R.G. Highly Efficient Aluminum-Catalyzed Ring-Opening Polymerization of Cyclic Carbonates, Lactones, and Lactides, Including a Unique Crystallographic Snapshot of an Intermediate. Organometallics 2011, 30, 3217-3224. [CrossRef]

39. Lamberti, M.; D'Auria, I.; Mazzeo, M.; Milione, S.; Bertolasi, V.; Pappalardo, D. Phenoxy-Thioether Aluminum Complexes as $\varepsilon$-Caprolactone and Lactide Polymerization Catalysts. Organometallics 2012, 31, 5551-5560. [CrossRef]

40. Hild, F.; Neehaul, N.; Bier, F.; Wirsum, M.; Gourlaouen, C.; Dagorne, S. Synthesis and Structural Characterization of Various N,O,N-Chelated Aluminum and Gallium Complexes for the Efficient ROP of Cyclic Esters and Carbonates: How Do Aluminum and Gallium Derivatives Compare? Organometallics 2013, 32, 587-598. [CrossRef]

41. McKeown, P.; Davidson, M.G.; Kociok-Köhn, G.; Jones, M.D. Aluminium Salalens vs. Salans: "Initiator Design" for the Isoselective Polymerisation of rac-Lactide. Chem. Commun. 2016, 52, 10431-10434. [CrossRef] [PubMed]

42. Stasiw, D.E.; Mandal, M.; Neisen, B.D.; Mitchell, L.A.; Cramer, C.J.; Tolman, W.B. Why So Slow? Mechanistic Insights from Studies of a Poor Catalyst for Polymerization of $\varepsilon$-Caprolactone. Inorg. Chem. 2017, 56, 725-728. [CrossRef] [PubMed]

43. Beament, J.; Mahon, M.F.; Buchard, A.; Jones, M.D. Aluminum Complexes of Monopyrrolidine Ligands for the Controlled Ring-Opening Polymerization of Lactide. Organometallics 2018, 37, 1719-1724. [CrossRef]

44. Macaranas, J.A.; Luke, A.M.; Mandal, M.; Neisen, B.D.; Marell, D.J.; Cramer, C.J.; Tolman, W.B. Sterically Induced Ligand Framework Distortion Effects on Catalytic Cyclic Ester Polymerizations. Inorg. Chem. 2018, 57, 3451-3457. [CrossRef]

45. Ropson, N.; Dubois, P.; Jerome, R.; Teyssie, P. Macromolecular Engineering of Polylactones and Polylactides. 20. Effect of Monomer, Solvent, and Initiator on the Ring-Opening Polymerization as Initiated with Aluminum Alkoxides. Macromolecules 1995, 28, 7589-7598. [CrossRef]

46. Lewiński, J.; Horeglad, P.; Wójcik, K.; Justyniak, I. Chelation Effect in Polymerization of Cyclic Esters by Metal Alkoxides: Structure Characterization of the Intermediate Formed by Primary Insertion of Lactide into the Al-OR Bond of an Organometallic Initiator. Organometallics 2005, 24, 4588-4593. [CrossRef]

47. Parenté, V.; Brédas, J.-L.; Dubois, P.; Ropson, N.; Jérôme, R. Theoretical Investigation of the Molecular Structure of Aluminium Triisopropoxide and its Complexes in Ring-Opening Polymerization. Macromol. Theory Simul. 1996, 5, 525-546. [CrossRef] 
48. Chen, Y.-H.; Chen, Y.-J.; Tseng, H.-C.; Lian, C.-J.; Tsai, H.-Y.; Lai, Y.-C.; Hsu, S.C.N.; Chiang, M.Y.; Chen, H.-Y. Comparing $l$-Lactide and $\varepsilon$-Caprolactone Polymerization by Using Aluminum Complexes Bearing Ketiminate Ligands: Steric, Electronic, and Chelating Effects. RSC Adv. 2015, 5, 100272-100280. [CrossRef]

49. Tseng, H.-C.; Chiang, M.Y.; Lu, W.-Y.; Chen, Y.-J.; Lian, C.-J.; Chen, Y.-H.; Tsai, H.-Y.; Lai, Y.-C.; Chen, H.-Y. A Closer Look at $\varepsilon$-Caprolactone Polymerization Catalyzed by Alkyl Aluminum Complexes: The Effect of Induction Period on Overall Catalytic Activity. Dalton Trans. 2015, 44, 11763-11773. [CrossRef]

50. Chang, M.-C.; Lu, W.-Y.; Chang, H.-Y.; Lai, Y.-C.; Chiang, M.Y.; Chen, H.-Y.; Chen, H.-Y. Comparative Study of Aluminum Complexes Bearing N,O- and N,S-Schiff Base in Ring-Opening Polymerization of $\varepsilon$-Caprolactone and $l$-Lactide. Inorg. Chem. 2015, 54, 11292-11298. [CrossRef]

51. Chang, C.-C.; Chang, Y.-C.; Lu, W.-Y.; Lai, Y.-C.; Wu, K.-H.; Lin, Y.-F.; Chen, H.-Y. Novel Aluminum Complexes Bearing 2-(Aminomethylene)malonate Ligands with High Efficiency and Controllability in Ring-Opening Polymerization of $\varepsilon$-Caprolactone. Eur. Polym. J. 2019, 115, 399-408. [CrossRef]

52. Mandal, M.; Luke, A.M.; Dereli, B.; Elwell, C.E.; Reineke, T.M.; Tolman, W.B.; Cramer, C.J. Computational Prediction and Experimental Verification of $\varepsilon$-Caprolactone Ring-Opening Polymerization Activity by an Aluminum Complex of an Indolide/Schiff-Base Ligand. ACS Catal. 2019, 9, 885-889. [CrossRef]

53. Von Schenck, H.; Ryner, M.; Albertsson, A.-C.; Svensson, M. Ring-Opening Polymerization of Lactones and Lactides with Sn(IV) and Al(III) Initiators. Macromolecules 2002, 35, 1556-1562. [CrossRef]

54. Marshall, E.L.; Gibson, V.C.; Rzepa, H.S. A Computational Analysis of the Ring-Opening Polymerization of rac-Lactide Initiated by Single-Site $\beta$-Diketiminate Metal Complexes: Defining the Mechanistic Pathway and the Origin of Stereocontrol. J. Am. Chem. Soc. 2005, 127, 6048-6051. [CrossRef] [PubMed]

55. Miranda, M.O.; DePorre, Y.; Vazquez-Lima, H.; Johnson, M.A.; Marell, D.J.; Cramer, C.J.; Tolman, W.B. Understanding the Mechanism of Polymerization of $\varepsilon$-Caprolactone Catalyzed by Aluminum Salen Complexes. Inorg. Chem. 2013, 52, 13692-13701. [CrossRef] [PubMed]

56. Vieira, I.d.S.; Whitelaw, E.L.; Jones, M.D.; Herres-Pawlis, S. Synergistic Empirical and Theoretical Study on the Stereoselective Mechanism for the Aluminum Salalen Complex Mediated Polymerization of rac-Lactide. Chem. Eur. J. 2013, 19, 4712-4716. [CrossRef]

57. Roymuhury, S.K.; Chakraborty, D.; Ramkumar, V. Aluminium Complexes Bearing N,O-Aminophenol Ligands as Efficient Catalysts for the Ring Opening Polymerization of Lactide. Eur. Polym. J. 2015, 70, 203-214. [CrossRef]

58. Jitonnom, J.; Molloy, R.; Punyodom, W.; Meelua, W. Theoretical Studies on Aluminum Trialkoxide-Initiated Lactone Ring-Opening Polymerizations: Roles of Alkoxide Substituent and Monomer Ring Structure. Computa. Theor. Chem. 2016, 1097, 25-32. [CrossRef]

59. Chandanabodhi, D.; Nanok, T. A DFT Study of the Ring-Opening Polymerization Mechanism of $l$-Lactide and $\varepsilon$-Caprolactone Using aluminium Salen-Type Initiators: Towards an Understanding of their Reactivities in Homo- and Copolymerization. Mol. Catal. 2017, 436, 145-156. [CrossRef]

60. Robert, C.; Schmid, T.E.; Richard, V.; Haquette, P.; Raman, S.K.; Rager, M.-N.; Gauvin, R.M.; Morin, Y.; Trivelli, X.; Guérineau, V.; et al. Mechanistic Aspects of the Polymerization of Lactide Using a Highly Efficient Aluminum(III) Catalytic System. J. Am. Chem. Soc. 2017, 139, 6217-6225. [CrossRef]

61. Wei, J.; Riffel, M.N.; Diaconescu, P.L. Redox Control of Aluminum Ring-Opening Polymerization: A Combined Experimental and DFT Investigation. Macromolecules 2017, 50, 1847-1861. [CrossRef]

62. Li, P.; Xi, Y.; Li, L.; Li, H.; Sun, W.-H.; Lei, M. A DFT Study on Ring-Opening Polymerization of $\varepsilon$-Caprolactone Initiated by $\mathrm{Mg}$ and $\mathrm{Al} \mathrm{Complexes.} \mathrm{Inorg.} \mathrm{Chim.} \mathrm{Acta} \mathrm{2018,} \mathrm{477,} \mathrm{34-39.} \mathrm{[CrossRef]}$

63. Frisch, M.J.; Trucks, G.W.; Schlegel, H.B.; Scuseria, G.E.; Robb, M.A.; Cheeseman, J.R.; Scalmani, G.; Barone, V.; Petersson, G.A.; Nakatsuji, H.; et al. Gaussian 16 Rev. A.03. Wallingford CT. 2016. Available online: https://gaussian.com/citation (accessed on 14 September 2019).

64. Ditchfield, R.; Hehre, W.J.; Pople, J.A. Self-Consistent Molecular-Orbital Methods. IX. An Extended Gaussian-Type Basis for Molecular-Orbital Studies of Organic Molecules. J. Chem. Phys. 1971, 54, 724-728. [CrossRef]

65. Hehre, W.J.; Ditchfield, R.; Pople, J.A. Self-Consistent Molecular Orbital Methods. XII. Further Extensions of Gaussian-Type Basis Sets for Use in Molecular Orbital Studies of Organic Molecules. J. Chem. Phys. 1972, 56, 2257-2261. [CrossRef]

66. Hariharan, P.C.; Pople, J.A. The influence of Polarization Functions on Molecular Orbital Hydrogenation Energies. Theoretica chimica acta 1973, 28, 213-222. [CrossRef] 
67. Francl, M.M.; Pietro, W.J.; Hehre, W.J.; Binkley, J.S.; Gordon, M.S.; DeFrees, D.J.; Pople, J.A. Self-Consistent Molecular Orbital Methods. XXIII. A Polarization-Type Basis set for Second-Row Elements. J. Chem. Phys. 1982, 77, 3654-3665. [CrossRef]

68. Lee, C.; Yang, W.; Parr, R.G. Development of the Colle-Salvetti Correlation-Energy Formula into a Functional of the Electron Density. Phys. Rev. B 1988, 37, 785-789. [CrossRef]

69. Becke, A.D. Density-Functional Thermochemistry. III. the Role of Exact Exchange. J. Chem. Phys. 1993, 98, 5648-5652. [CrossRef]

70. Stephens, P.J.; Devlin, F.J.; Chabalowski, C.F.; Frisch, M.J. Ab Initio Calculation of Vibrational Absorption and Circular Dichroism Spectra Using Density Functional Force Fields. J. Chem. Phys. 1994, 98, 11623-11627. [CrossRef]

71. Grimme, S. Semiempirical GGA-Type Density Functional Constructed with a Long-Range Dispersion Correction. J. Comput. Chem. 2006, 27, 1787-1799. [CrossRef]

72. Tomasi, J.; Mennucci, B.; Cammi, R. Quantum Mechanical Continuum Solvation Models. Chem. Rev. 2005, 105, 2999-3094. [CrossRef] [PubMed]

73. Fukui, K. Formulation of the Reaction Coordinate. J. Phys. Chem. 1970, 74, 4161-4163. [CrossRef]

74. Fukui, K. The Path of Chemical Reactions-the IRC Approach. Acc. Chem. Res. 1981, 14, 363-368. [CrossRef]

75. Gonzalez, C.; Schlegel, H.B. Reaction Path Following in Aass-Weighted Internal Voordinates. J. Phys. Chem. 1990, 94, 5523-5527. [CrossRef]

76. Maeda, S.; Harabuchi, Y.; Ono, Y.; Taketsugu, T.; Morokuma, K. Intrinsic Reaction Coordinate: Calculation, Bifurcation, and Automated Search. Int. J. Quantum Chem. 2015, 115, 258-269. [CrossRef]

77. Chan, M.S.W.; Deng, L.; Ziegler, T. Density Functional Study of Neutral Salicylaldiminato Nickel(II) Complexes as Olefin Polymerization Catalysts. Organometallics 2000, 19, 2741-2750. [CrossRef]

(C) 2019 by the authors. Licensee MDPI, Basel, Switzerland. This article is an open access article distributed under the terms and conditions of the Creative Commons Attribution (CC BY) license (http://creativecommons.org/licenses/by/4.0/). 